\title{
Changes in composition of rat's milk in the stomach of the suckling
}

\author{
By D. J. NAISMITH \\ Department of Nutrition, Queen Elizabeth College, London, W8 \\ AND
}

ADELE MITTWOCH AND B. S. PLATT*

Department of Nutrition, London School of Hygiene and Tropical Medicine London, $W C_{\mathrm{I}}$

\section{(Received I 5 Fanuary I969-Accepted 13 March I969)}

\begin{abstract}
I. A study was made of the partition of the major constituents of rat's milk during the formation of the clot in the infant rat's stomach.

2. Milk was obtained from the dams by manual expression after separation from their litters for periods ranging from 12 to $23 \mathrm{~h}$.

3. The ratio of fat to protein in the clots removed from the stomachs of the I 1 -day-old pups was more than double that found in the milk. The difference was due to the high fat content of the clot.

4. The stomach contents of pups which were allowed to suckle for $I \mathrm{~h}$ following a $\mathrm{I} 2 \mathrm{~h}$ separation from their dams had a fat to protein ratio similar to that of the expressed milk. When suckling was prolonged, the ratio reverted to that of the established clot.

5. Milk secreted under conditions of uninterrupted lactation and promptly recovered from the stomachs of pups previously fasted had a value for fat to protein comparable to that for the clot from a normally fed pup. An interruption in suckling therefore reduced the fat content of the milk.

6. Part of the carbohydrate in rat's milk is secreted in a bound form. Lactose accounts for approximately one half of the total carbohydrate. Evidence is presented which suggests that the remainder may be an isomer of lactose.

7. Fat and lactose undergo hydrolysis to a small extent only in the pup's stomach. The breakdown of protein is insignificant. Rat's milk contains no proteolytic enzymes.

8. No significant differences in composition were found in the outer shell, the core and pyloric regions of the clot. Thus fat and casein leave the stomach in constant proportion.
\end{abstract}

The nursing rat feeds her young at frequent intervals throughout the day and night. The normally fed infant rat's stomach is never empty; the stomach and its contents are clearly visible through the abdominal wall, and the contents may be shelled out as a cohesive cheesy mass. Platt (196I) noted that the clot was structured in layers, and has described the manner in which this stratification takes place. When the infant rat was allowed to suckle alternately from its mother and from a foster mother secreting coloured milk, following the injection of Trypan blue, it was demonstrated that the concentric shells were formed by newly entering milk enveloping the coagulum that remained from previous feeds. The order in which the layers were laid down was thus the reverse of the typical pattern obtained by Grutzner (I905) when feeding bread paste to adult animals. In this instance, the most recently ingested solid food was found in the centre of the stomach contents.

In studies of the rate of emptying of the stomach of the normally fed infant rat,

\footnotetext{
* Professor Platt died on I8 July I969.
} 
Platt (I96I) found residues in the stomach of marked milk ingested $20 \mathrm{~h}$ previously. A very different picture is presented when the normal feeding practice is interrupted. Examination of the stomach and gut contents of infant rats suckled after a prolonged fast showed that the first portion of milk left the stomach almost at once, without forming a clot. The remainder formed an undifferentiated curd with much mucus and many air pockets. From 3 to $4 \mathrm{~h}$ after feeding in this way, the ratio of casein to whey protein in the clot was still very low in comparison with that found for a normally fed pup (Guminski \& Naismith, 1959). When feeding was resumed, stratification throughout the clot was established only after I-2 days.

On the basis of moisture and sugar levels within the clot, it was calculated that almost two-thirds of the whey leaves the stomach $30-40 \mathrm{~min}$ after ingestion (Borrow \& Platt, 195I). The remainder, which permeates the clot, is displaced by fresh whey. Emptying of the curd fraction is by a process of erosion in the pyloric antrum, where the partly digested clot can be seen stained yellow by bile. Regurgitated duodenal secretions may well play a part in the digestive processes.

The object of the present investigation was to obtain a clearer picture of how the milk constituents distribute themselves after ingestion, and to study the changes that occur during the long stay of milk in the stomach.

\section{EXPERIMENTAL}

The experimental work falls into two parts. In the first, the composition of rat's milk and of the stomach contents of infant rats at various intervals after suckling was determined. In addition, variations in composition in different parts of the milk clot were studied. The second part of the investigation arose from the unexpected observation that the ratio of fat to protein found in freshly expressed milk had a value less than half that found in the stomach contents of the suckling rat. The experiments are described in the order in which they were performed.

\section{Procedure}

Expt I. Rats of the Sprague-Dawley strain were used and were maintained on stock diet 4I B (Bruce \& Parkes, 1947). Eight litters of I I-day-old rats were separated from their mothers and kept without food at $37^{\circ}$ in a moist atmosphere. Five groups were selected at random; one group $(\mathrm{O})$ was killed immediately, and the remaining groups after $\mathrm{I}, 3,5$ or $7 \mathrm{~h}$. Their stomachs were rapidly dissected, frozen in solid $\mathrm{CO}_{2}$ and stored at $-20^{\circ}$. The stomachs were later thawed sufficiently for the walls to be removed, and the stomach contents from each group were weighed and pooled for analyses. The $3 \mathrm{~h}$ and $5 \mathrm{~h}$ samples were freed from bile and mucus, as far as possible, before weighing. The $7 \mathrm{~h}$ sample was too small for accurate analyses.

The eight dams were milked, 20-23 $\mathrm{h}$ after the removal of their litters, by manual stripping of the glands under ether anaesthesia (Cox \& Mueller, 1937; Glass, 1956). The pooled milk sample $(2 \mathrm{~g})$ was stored at $-20^{\circ}$. The composition of the samples was determined with respect to the following: total solids, fat and fatty acids, total $\mathrm{N}$, protein and non-protein $\mathrm{N}(\mathrm{NPN})$, total carbohydrate, a semi-quantitative distribution 
of constituent carbohydrates by paper chromatography, and a rough comparison of amino acids and peptides in the NPN fractions by paper chromatography. All analytical procedures are given below.

Expt 2. Black and white hooded rats of the Institute's colony were maintained on diet $4 \mathrm{I} B$ supplemented with liver from the $4^{\text {th }}$ day before parturition to the end of the lactation period. Eight litters of I I-day-old pups were killed and the stomachs rapidly removed and frozen. The stomachs were later thawed sufficiently to be sectioned. The pyloric funnel was cut off, and its contents separated from the viscus. The remainder was cut in half along its greater curvature. The core was scooped from each half, and the residue removed from the stomach wall. Three pooled samples were prepared in this way, namely outer shell $(\mathrm{I} I \cdot \mathrm{I})$, core $(\mathrm{I} I \cdot 8 \mathrm{~g})$ and pylorus $(2 \cdot 2 \mathrm{~g})$. The eight dams were milked, as previously described, I2-I $6 \mathrm{~h}$ after separation from their young. The yield of milk was $10.8 \mathrm{~g}$. All samples were stored at $-20^{\circ}$ and freeze-dried before analysis. The same analyses were performed as in Expt $I$, with the omission of the two-dimensional paper chromatography of amino acids. The volume of milk permitted, in addition, a test for the presence of proteolytic enzyme activity. I $\mathrm{ml}$ of fresh milk was analysed for protein and NPN; a second sample was incubated for $3 \mathrm{~h}$ at $37^{\circ}$ before analysis.

In subsequent experiments the strain of rat and dietary treatment were as described in Expt 2.

Expt 3. Two litters of nine I I-day-old pups were separated from their dams. Two pups were killed immediately to act as controls. The remainder were fasted for $\mathrm{I} 2 \mathrm{~h}$, then allowed to suckle continuously before killing, in groups of 4 , after $1,4,7$ and $24 \mathrm{~h}$. Milk clots were removed from the stomachs of all pups for the determination of fat and protein.

Expt 4. In Expts $\mathrm{I}-3$ dams were removed from their pups for at least $\mathrm{I} 2 \mathrm{~h}$ in order to allow milk to accumulate. Milk samples were obtained by manual expression, or recovered from the stomachs of pups after a short period of suckling. Expt 4 was undertaken to determine whether this interruption in suckling had altered the composition of rat's milk. From a litter of I I-day-old pups, five were removed for a $\mathrm{I} 2 \mathrm{~h}$ period (group A), and five were allowed to remain with the mother (group B). The lactation of the dam was therefore continuous. The two half-litters were then exchanged. The fasted group A were permitted to feed for I $h$, then were killed. The milk recovered from their stomachs had therefore been obtained under normal conditions of lactation. Two pups from group B were killed immediately. Their stomachs contained normal milk clots. The remaining three pups of group B were kept apart from the mother for $\mathrm{I} 2 \mathrm{~h}$, then were returned to feed for $\mathrm{I} h$ before killing. The milk thus obtained was the product of interrupted suckling. The stomach contents of all pups were removed immediately after death for analyses. This experiment was repeated, and the analytical results were combined. 


\section{Analyses}

Total solids and water. Samples were dispersed in a little water and spread evenly over tared milk bottle top blanks, previously freed from grease. Heating for $\mathrm{I} h$ at $100^{\circ}$ was found adequate to reduce them to constant weight.

Fat and fatty acids. Fat was extracted from freeze-dried samples with petroleum spirit (boiling point $60-80^{\circ}$ ) using a Soxhlet apparatus. Total fat was determined gravimetrically. A portion of the fat was dissolved in a $\mathrm{I}: \mathrm{I}$ mixture of neutralized ethanol-benzene for estimation of free fatty acids. The solution was heated, and titrated with $0.04 \mathrm{~N}$-alcoholic $\mathrm{NaOH}$, using phenolphthalein as indicator.

Total $N$ and protein. Total $\mathrm{N}$ was determined on the fat-extracted residue by a standard Kjeldhal procedure, using metallic mercury as catalyst.

For the estimation of total protein, the method of Glass (I956) was employed.

Paper chromatography of amino acids. A suspension of the freeze-dried sample was ultrafiltered by the method of Smith (1958), the ultrafiltrate de-salted by the method of Whitehead \& Whittaker (1955) and a $10 \%$ solution (w/v) prepared in $10 \%(\mathrm{v} / \mathrm{v})$ isopropanol. Hydrolysis was carried out by refluxing, for $16 \mathrm{~h}$, a solution of $2 \%(\mathrm{w} / \mathrm{v})$ de-proteinized sample in $6.3 \mathrm{~N}-\mathrm{HCl}$. This was followed by removal of $\mathrm{HCl}$ under reduced pressure, and desalting. Two-dimensional chromatograms were run using $0.15 \mathrm{ml}$ of each prepared solution, containing approximately a $15 \mathrm{mg}$ sample. Details of chromatography are given by Smith (1958).

Total carbohydrate. Analysis for carbohydrate was made by the anthrone procedure of Mittwoch (1965).

Paper chromatography of sugars. The method was an adaptation of that of Roberts, Pettinatti \& Bucek (1954). The samples were deproteinized with barium and zinc reagents (Somogyi, 1945), desalted with hot pyridine, and the final residues were taken up in $10 \%$ isopropanol. Standards of lactose, glucose and galactose were subjected to the same procedure. The 'universal' tank and the ascending 'pad' techniques described by Smith (1958) were used. The solvent was Smith's monophasic ethylacetate-pyridine-water mixture made $0^{\circ}{ }^{1} 5 \mathrm{M}$ with respect to $\mathrm{AgNO}_{3}$. After an overnight run, the chromatograms were developed by the method of Roberts et al. (1954). The spots appeared during the heating period, but continued to increase in intensity for several days. The sheets were stored in the dark to prevent excessive darkening of the background. The spots were evaluated by visual matching 2 days after development; an accuracy of about $20 \%$ was achieved in the ranges of $\mathrm{I}-20 \mu \mathrm{g}$ lactose, and $0.5^{-10} \mu \mathrm{g}$ mixed monosaccharides. Hydrolysis and treatment of the hydrolysate were carried out by the method of Partridge (1948); $0.5 \mathrm{~N}-\mathrm{H}_{2} \mathrm{SO}_{4}$ and a $4 \mathrm{~h}$ period of heating were used.

Salts. Salts were not estimated directly, but by calculation from other analytical results.

\section{RESULTS}

Expt $\mathrm{r}$. The stomachs of the pups killed at once were distended and filled with the typical clot, occasionally stained yellow by bile near the pylorus. The mean weight 
(nine pups) of the individual stomach contents was $0.5 \mathrm{~g}$. The appearance and weight of the clot was unchanged after $\mathrm{I} h$ (twelve pups), indicating that food passes very slowly from the stomach of the normally fed infant rat. The stomachs had partially collapsed $3 \mathrm{~h}$ after feeding (twelve pups), and the remaining curd, which was admixed with a little bile, weighed only $0.26 \mathrm{~g}$. This was further reduced to $0.05 \mathrm{~g}$ after $5 \mathrm{~h}$ (twelve pups), and after $7 \mathrm{~h}$ (seven pups) the curd had practically disappeared. The analytical results are presented in Table $\mathrm{r}$. Results from the $5 \mathrm{~h}$ samples are considered less reliable because the amount of material available for analysis was small, and was contaminated with gastro-intestinal secretions.

Table 1. Composition of milk of albino rats on the 12 th day of lactation, expressed $20 \mathrm{~h}$ after removal of the pups, and of milk clots from the stomachs of I I-day old-pups at different times after separation from dams

(Values are expressed as percentage of wet weight)

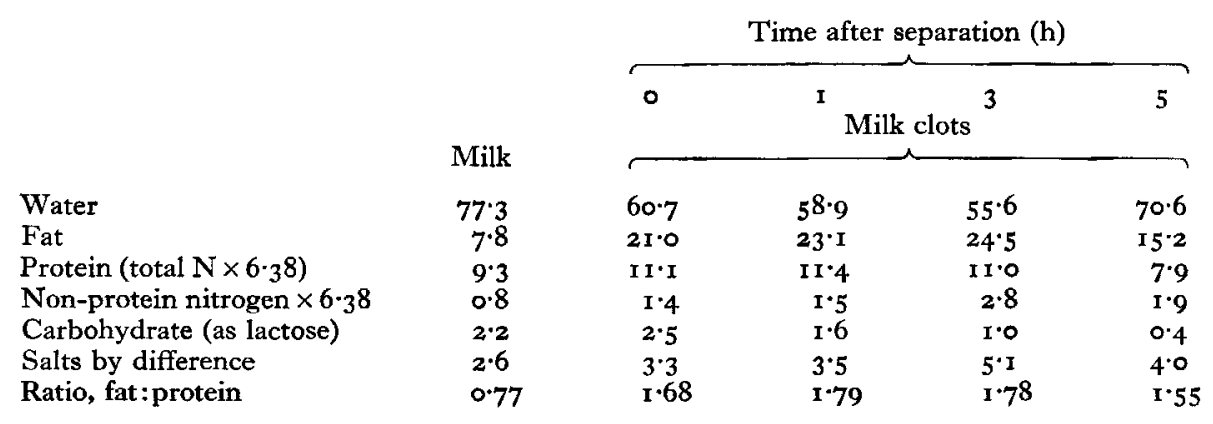

The composition of the residual clot, with respect to fat and protein, changed little with time. The ratio of fat to protein (total $N \times 6.38$ ) was not significantly different after $3 \mathrm{~h}$, by which time half of the original clot had left the stomach. This value was, however, more than double that found for milk expressed from the dams some $20 \mathrm{~h}$ after separation from their litters, the difference being due largely to the greater concentration of fat in the milk clot. The amount of NPN in the stomach increased with time. Chromatography of the milk gave one spot only, which was believed to be glutamic acid. More free amino acids appeared on the chromatograms of the stomach contents, notably in the positions occupied by alanine, leucine and isoleucine, phenylalanine and, to a lesser extent, valine and/or methionine, glutamine and serine. The amounts present were very small, but rose steadily from $\circ$ to $5 \mathrm{~h}$. After hydrolysis of the ultrafiltrates from the stomach contents, all the amino acids commonly found in proteins were detected. It was concluded that the NPN fraction contained only a small proportion of free amino acids, and much larger amounts of peptides of molecular weight too high to react with ninhydrin, but low enough to pass through the ultrafilter membrane.

The concentration of carbohydrate was higher and the water content lower in milk clots from pups newly separated from their dams than in expressed milk. Since free lactose would be expected to leave the stomach with the water, this finding suggested 
that part of the carbohydrate was in a bound form, bound presumably to protein. The decrease in sugar concentration, ultimately to a value well below that for milk, further suggested that bound sugar was released, and that the whey was diluted with a sugarfree secretion or that sugar had been absorbed through the stomach wall. Chromatography for carbohydrates revealed lactose, and small amounts of glucose and galactose in the stomach contents, and on all chromatograms a spot of lower $R_{f}$ value than that of lactose. The total amount of carbohydrate that appeared on the chromatograms was substantially less than expected from the anthrone determinations on the original samples. Treatment before chromatography, i.e. deproteinization and desalting, could not account for the loss, as the sugar standards were subjected to the same procedures. The anthrone determinations did not, however, involve deproteinization, and this treatment might remove bound sugar along with protein. Alternatively, bound sugar

Table 2. Composition of milk of albino rats, expressed 20 h after removal of the litter, and of milk clots from the stomachs of II-day-old albino rats at different times after separation from dams

\begin{tabular}{|c|c|c|c|c|c|}
\hline & & \multicolumn{4}{|c|}{ Time after separation (h) } \\
\hline & & 0 & I & 3 & 5 \\
\hline & Milk & \multicolumn{4}{|c|}{ Milk clots } \\
\hline $\begin{array}{l}\text { Free fatty acids ( } \% \text { of } \\
\text { total fat) }\end{array}$ & 4.8 & $6 \cdot 3$ & $7 \cdot 8$ & $9 \cdot 4$ & $12 \cdot 5$ \\
\hline $\begin{array}{l}\text { Non-protein nitrogen (\% of } \\
\text { total } N \text { ) }\end{array}$ & $8 \cdot 6$ & $11 \cdot 2$ & $11 \cdot 6$ & $20 \cdot 3$ & 19.4 \\
\hline $\begin{array}{l}\text { Monosaccharides ( } \% \text { of total } \\
\text { carbohydrate) }\end{array}$ & 0.0 & $3 \cdot 0$ & $8 \cdot 0$ & $10 \cdot 0$ & $5 \cdot 0$ \\
\hline
\end{tabular}

might be insoluble in hot pyridine. An exact estimate of the amount lost was impossible because standards were not available for the unidentified sugar or sugar complex. The amount of total carbohydrate recovered from the chromatograms was greatest for the $\mathrm{I} \mathrm{h}$ milk clot, less for the $\circ \mathrm{h}$ sample and least for fresh milk, again suggesting the release of sugar from a bound form.

The progress of digestion in the stomach of the infant rat is summarized in Table 2. All the major components of milk undergo hydrolysis, but to a very limited extent.

Expt 2. The composition of milk from hooded rats (Table 3) was very similar to that from the albino rats used in Expt $I$ and agreed with the values reported by Glass (1956). No significant differences were found in the fat, protein and NPN content of samples taken from the three different parts of the milk clot; the ratios of fat to protein were essentially the same. The stomach contents again contained relatively more fat than was found in the expressed milk, leading to a value for fat to protein which was more than double that for milk.

The values for carbohydrate concentration in the three parts of the clot are comparable with those found for stomach contents in Expt $\mathrm{I}$, and, in relation to water content, show the same trend with time, if it is assumed that the curd of the outer shell has spent least time, and that of the pyloric region most time in the infant rat's stomach. This assumption is supported by the results recorded in Table 4, which shows the 
degree of digestion of the major constituents of milk in the various parts of the clot. Both fat and lactose undergo some hydrolysis before passing into the duodenum. The breakdown of protein is, however, insignificant. The milk itself contains no proteolytic enzymes; a sample of fresh milk, incubated at $37^{\circ}$ for $3 \mathrm{~h}$, showed no increase in NPN.

Table 3. Composition of milk of hooded rats on the 12th day of lactation, expressed $\mathrm{I} 2 \mathrm{~h}$ after removal of the litter, and of different parts of milk clots from the stomachs of I Iday-old pups

(Values are expressed as a percentage of wet weight)

\begin{tabular}{|c|c|c|c|c|}
\hline & & & ilk clot & \\
\hline & Milk & $\begin{array}{c}\text { Outer } \\
\text { shell }\end{array}$ & Core & Pylorus \\
\hline Water & $78 \cdot 7$ & $52 \cdot 0$ & $55^{\circ} 7$ & $5^{8 \cdot 9}$ \\
\hline Fat & 7.8 & $28 \cdot 6$ & $26 \cdot 0$ & $24 \cdot 6$ \\
\hline Protein (total $N \times 6.3^{8}$ ) & $8 \cdot 2$ & $12 \cdot 6$ & $12 \cdot 5$ & $10 \cdot 8$ \\
\hline Non-protein nitrogen $\times 6.38$ & 0.6 & $1 \cdot 6$ & $I \cdot 4$ & $I \cdot 6$ \\
\hline Carbohydrate (as lactose) & $2 \cdot 4$ & $1 \cdot 9$ & $I-6$ & $\mathrm{I} \cdot 2$ \\
\hline Salts (by difference) & $2 \cdot 3$ & 3.3 & $2 \cdot 8$ & $2 \cdot 9$ \\
\hline Ratio, fat: protein & 0.89 & $\begin{array}{ll}3.0 \\
2.01\end{array}$ & $r \cdot 87$ & I.98 \\
\hline
\end{tabular}

Table 4. Composition of milk of hooded rats, expressed i2 $h$ after removal of the litter, and of different parts of milk clots from the stomachs of $\mathrm{I} \mathrm{I}$-day-old hooded rats

\begin{tabular}{|c|c|c|c|c|}
\hline & & \multicolumn{3}{|c|}{ Milk clots } \\
\hline & Milk & $\begin{array}{l}\text { Outer } \\
\text { shell }\end{array}$ & Core & Pylorus \\
\hline $\begin{array}{l}\text { Free fatty acids ( } \% \text { of total } \\
\text { fat) }\end{array}$ & 0.6 & $6 \cdot 3$ & $8 \cdot 6$ & I 3.9 \\
\hline $\begin{array}{l}\text { Non-protein nitrogen (\% of } \\
\text { total } N \text { ) }\end{array}$ & $7 \cdot 0$ & $I I \cdot I$ & $9 \cdot 9$ & I $3 \cdot I$ \\
\hline $\begin{array}{l}\text { Monosaccharides ( } \% \text { of total } \\
\text { carbohydrate) }\end{array}$ & 0.0 & $I \cdot O$ & $3 \cdot 0$ & $5^{\circ} \circ$ \\
\hline
\end{tabular}

The solutions prepared for sugar chromatography were analysed for total carbohydrate by the anthrone method. The recoveries were 97,89 and $8 \mathrm{I}$ and $10 \mathrm{r} \%$ for milk and the three portions of the stomach contents respectively. On chromatography, all samples gave spots of lactose equivalent to about half the total carbohydrate present, and spots of lower $R_{f}$ value almost equal in intensity to those of lactose. In addition, the stomach contents, but not the milk, gave spots of glucose and galactose and also a faint and transient spot with an $R_{f}$ value of $\mathrm{I} \cdot 82$ (in isopropanol-water) which increased in intensity pari passu with those of the monosaccharides.

Chromatograms of the prepared solutions were tested with ninhydrin. The resulting streaks increased in length and depth with increasing NPN content of the samples, but there was no intensification of the colour reaction of the unidentified carbohydrate. There was, therefore, no evidence that the substance contains any free amino acid. Glucosamine was detected in a mixed hydrolysate of the samples. The amount 
represented about $0.8 \%$ of the total carbohydrate. Fucose was not detected. The hydrolysate of the bulked sample was found to be made up of $20 \%$ lactose and about $80 \%$ of hydrolysed lactose, with a faint spot in the position of the original unidentified fraction. An approximately quantitative yield, expressed as total carbohydrate, was obtained. Pure lactose was found to be hydrolysed, under the same conditions, to the extent of about $80 \%$ only.

Table 5. Expt 3. Composition of the stomach contents of I I-day-old rat pups. The control pups were normally suckled; the remainder were separated from their dam for $12 \mathrm{~h}$, then returned to suckle her for the period indicated

$\begin{array}{ccc}\text { Suckling period (h) } & \text { No. of pups } & \text { Ratio, fat: protein } \\ \text { Control } & 2 & \mathrm{I} \cdot 9 \mathrm{I} \\ 1 & 4 & 0 \cdot 72 \\ 4 & 4 & \mathrm{I} \cdot 28 \\ 7 & 4 & \mathrm{I} \cdot 43 \\ 24 & 4 & \mathrm{I} \cdot 90\end{array}$

Table 6. Expt 4. Composition of the stomach contents of I I-day-old rat pups

$\begin{array}{lcc}\begin{array}{l}\text { Unfasted pups suckling } \\ \text { normal dam (group B) }\end{array} & 4 & \text { I'75 } \\ \begin{array}{l}\text { Pups fasted } 12 \text { h then } \\ \text { suckling normal dam (group A) }\end{array} & \text { I0 } & \text { I.37 } \\ \begin{array}{l}\text { Pups fasted } 12 \text { h then suckling } \\ \text { dam I2 h after removal of her }\end{array} & 6 & 0.77 \\ \quad \text { litter (group B) }\end{array}$

No. of pups Ratio, fat: protein

Expt 3. The stomach contents of infant rats were analysed for protein and fat at various times after continuous suckling was re-established, following a $\mathrm{I} 2 \mathrm{~h}$ separation of dam and pups. The results are recorded in Table 5. The stomachs of all pups contained large clots at the time of killing. The ratio of fat to protein in the clot $\mathrm{I} h$ after suckling commenced was of the same order as that in the expressed milk (Table 3 ). The value rose as the period of feeding was prolonged until, after $24 \mathrm{~h}$, it equalled that in the clots obtained from normally-fed pups.

Expt 4. In Table 6 the composition of milk, obtained from the stomachs of pups, during normal lactation (group $\mathrm{A}$ ) is compared with that following a $12 \mathrm{~h}$ interruption of suckling (group B). Although the fasted pups were given access to the dam for $\mathrm{I} h$, much of this time was used by the mother to clean her pups before feeding began. Consequently the stomach contents had the consistency of fresh milk rather than that of the established clot. The composition of normal milk clots (group B) is also shown in this table.

Following a $12 \mathrm{~h}$ separation from her litter, during which milk accumulated in the mammary glands, the rat secreted milk with a low fat to protein ratio. The value was similar to that for milk expressed under the same conditions (see Table 3), and less than half that found for the clot established during continuous feeding. Milk secreted under normal conditions and recovered from the stomachs of the pups of group A 
gave a value for fat to protein almost double that calculated for the milk from the fasted pups of group B.

\section{DISCUSSION}

The aim of this investigation was to elucidate the process whereby the major components of milk are separated in the stomach of the suckling rat. The most striking difference in composition between milk manually expressed from the dam $12 \mathrm{~h}$ or more after removal of her litter, and the clotted milk recovered from the normally suckling infant rat's stomach was in the ratio of fat to protein, the value for stomach contents being more than twice that for milk. This difference was due, predominantly, to an apparent increase in the concentration of fat in the stomach. During the continuous formation of the clot, its disintegration in the pyloric region and discharge into the duodenum, fat and protein were present in constant proportion. To account for a rise in the relative concentration of fat, it might be supposed that a considerable part of the casein escaped precipitation by rennin, and left the stomach along with the non-casein proteins. This explanation was not, however, upheld by the results of subsequent experiments.

When pups were allowed to resume feeding after a $12 \mathrm{~h}$ separation from the dam, the clot removed from the stomach after $\mathrm{I} h$ had a composition with respect to fat and protein, resembling that of expressed milk. If suckling was continued, the ratio of fat to protein in the clot rose gradually until, after $24 \mathrm{~h}$, it had returned to its original value. These observations suggested that the high fat content of the curd produced under normal conditions did not arise from the loss of casein during the development of the clot, but that the composition of the milk ingested was changing with time.

In the final experiment liquid milk was obtained from the stomachs of pups under normal conditions of suckling, and again, from the same dams, after a $\mathrm{I} 2 \mathrm{~h}$ interruption of suckling. The fat to protein ratio in the former milk sample approximated to that of a normal clot. If allowance is made for the loss of non-casein protein $(22 \%$ of the total protein) which occurs during the precipitation of the curd (Guminski \& Naismith, 1959), the small difference in values disappears. The fat to protein ratio in milk collected after an interval during which suckling was discontinued was reduced to almost half the normal value. This procedure has customarily been adopted in studies on the composition of rat's milk (Cox \& Mueller, 1937; Luckey, Mende \& Pleasants, I954; Glass, 1956). Consequently, the values for the ratio of fat to protein in milk, calculated from published data, are all substantialiy lower than our value for normal milk.

The present investigation has confirmed that sugar leaves the infant stomach at a faster rate than fat and the major protein of milk. The fall in the concentration of sugar may be due, in part, to the dilution of the stomach contents with saliva or tissue water entering via the stomach wall (Karel, r 948). On the question of sugar absorption from the stomach, much conflicting evidence is found in the literature. Karel (1948), who has made a critical study of the subject, concludes that absorption is probably negligible when the concentration of sugar is below $15 \%$. This is much higher than the concentration resulting from the intake of milk, but the possibility cannot be 
disregarded that the stomach wall may be more permeable to sugar during infancy than in later life.

Rat's milk was found to contain a carbohydrate other than lactose as a major component. Lactose, glucose, galactose and a fourth carbohydrate of lower $R_{f}$ value than lactose have been found in the stomach contents of newborn rats (Malyoth, Stein, Hormann \& Schuler, 1953). The relative amounts were not reported by these authors. The unidentified spot contained free glutamic acid but no free hexosamine. The suggestion that a link exists between the carbohydrate and glutamic acid is, however, open to doubt, since their superimposition in preparative chromatography may have been coincidental. Hydrolysis yielded glutamic acid, glucose and galactose. We did not confirm the presence of an amino acid in the unidentified carbohydrate. In the earlier investigation there was insufficient material to test for amino sugars, but the test was positive on hydrolysates of corresponding fractions from human and cow's milk. It was surmised, without further evidence, that the amino sugar was glucosamine, the work of Kuhn (1952) being cited in support of this belief, and that an additional sugar in human milk was fucose, i.e. the unknown fraction was associated with the bifidus factor. From the data of Kuhn (1952) and György (1958) we estimated that the bifidus factor in rat's milk constitutes about $7 \%$ of the total carbohydrate, much less than the unknown fraction in the present study. Roberts et al. (1954) obtained a spot of $R_{f}$

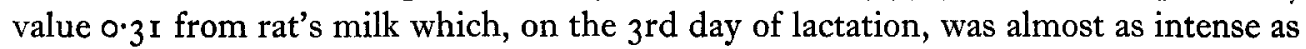
the lactose spot. Hydrolysis yielded glucose, galactose and traces of lactose. These authors inferred that lactose is a component part, or that the substance is an isomer of lactose. Our own analyses lend support to the latter suggestion.

In spite of the lengthy stay of food in the infant's stomach, little digestion takes place. Fat appears to be more susceptible to hydrolysis than the sugar or proteins. This may result from the presence of a lipase in rat's milk. As no proteolytic enzyme is present in milk, it seems likely that the limited degradation of protein, which was detected in the part of the clot recovered from the pyloric funnel, was due to regurgitation of digestive enzymes or products of digestion from the duodenum.

Since the stomach of the infant rat appears to play a relatively insignificant role in the digestion of food, the advantage of the layered clot may be that the major sources of protein and energy are discharged from the stomach at a rate commensurate with the digestive capacity of the immature intestine. Alternatively, the clot may function primarily as a reservoir of nutrients, thus protecting the newborn from intermittent periods of fasting.

\section{REFERENCES}

Borrow, A. \& Platt, B. S. (195I). F. Physiol., Lond. I12, 5 I P.

Bruce, H. M. \& Parkes, A. S. (1947). F. Hyg., Camb. 45, 70.

Cox, W. M. Jr \& Mueller, A. J. (1937). F. Nutr. r3, 249.

Glass, R. L. (1956). Chemical, physical, and biological studies on rat's milk and its components. PhD Thesis, University of Minnesota.

Grutzner, P. (1905). Pflügers Arch. ges. Physiol. 106, 463.

Guminski, T. \& Naismith, D. J. (1959). Proc. Nutr. Soc. r8, xxv.

György, P. (1958). Chemistry and Biology of Mucopolysaccharides. Ciba Foundation Symposium.

London: J. \& A. Churchill. 
Karel, L. (1948). Physiol. Rev. 28, 433.

Kuhn, R. (1952). Angew. Chem. 64, 493 .

Luckey, T. D., Mende, T. J. \& Pleasants, J. (1954). F. Nutr. 54, 345.

Malyoth, G., Stein, H. W., Hormann, E. \& Schuler, R. (1953). Experientia 9, 70.

Mittwoch, A. (1965). Analyst, Lond. 90, 759.

Partridge, S. M. (1948). Biochem. F. 42, 25 I.

Platt, B. S. (196r). Fedn Proc. Fedn Am. Socs exp. Biol. 20, No. 1, Part 3, p. 188.

Roberts, H. R., Pettinatti, J. D. \& Bucek, W. (1954). F. Dairy Sci. 37, 538.

Smith, I. (I958). Chromatographic Techniques. London: W. Heineman.

Somogyi, M. (1945). F. biol. Chem. 160, 69 .

Whitehead, T. P. \& Whittaker, S. R. E. (1955). F. clin. Path. 8, 8r. 